\title{
Transdisciplinary Teaching and Learning: an Experiment
}

\section{Antonella Giacosa}

Department of Foreign Languages, Literatures and Modern Cultures, Università degli Studi di Torino, Italy.

\begin{abstract}
In our smart new world, characterized by continuous technological evolution, knowledge is subject to rapid obsolescence and change is the only constant. In this context, teachers are called upon to overcome the automatic habits of traditional knowledge transmission by developing a new perspective less tied to individual disciplines and more open to the many facets of reality. Only with a questioning and curious attitude aimed at innovation and pedagogical experimentation can teachers make their message meaningful again and help new generations to develop the habit of flexible and complex thinking in order to orient themselves in a fluid, globally connected and hypertechnological society. Following a course on multidisciplinarity, a group of secondary school teachers embarked on a journey of reading and experimenting in the classroom, realizing that through the transdisciplinary approach theorized by the quantum physicist Nicolescu, one can educate for the future. This powerful new approach suggests that teachers identify and tackle conceptual issues to work on and then they overcome the narrow limits of individual disciplines in order to understand complex events: this is the direction in which teachers and students of today's school should move, so that they will face tomorrow with greater awareness and effectiveness.
\end{abstract}

Keywords: transdisciplinarity, complex thinking, pedagogical innovation, action research, teaching. 


\section{Introduction}

What do a quantum physicist, a Lacanian psychoanalyst, a philosopher, a specialist in education and a musicologist have in common? In this article, which deals with transdisciplinarity and ideas for a powerful new approach to teaching, we will try to answer this question and to identify possible implications for teaching. Actually, teachers are mostly motivated by good intentions, but they run the risk of being ineffective in helping their students develop an overall vision for making informed decisions (Harari 2018, p. 381).

To proceed in order, we will start from the background of this reflection. Following the suggestions of a refresher course on multidisciplinarity aimed at secondary school teachers (Borgogni 2018), we - a group of four English teachers, two Italian teachers and two Art History teachers - set out to create an innovative teaching module involving different disciplines to help our high school students face the new Italian state exam. According to Law 107/2015 (MIUR 2015), the new exam's aim is to verify that senior students are able to connect, critically and personally, the materials prepared by the exam commission with the knowledge they have acquired in the final year.

At the beginning of our action research experience, we undertook a series of readings aimed at understanding what is meant by multidisciplinarity, what new possibilities it opens up for teaching and how it responds to the needs of the fluid and hyper-technological society in which digital natives grow and learn. We started from a known terrain, namely the War Poets and the Futurist movement in Italian literature and in Art History, but we soon found ourselves facing the topic from points of view related to different disciplines, which in our experience is a still unusual and unconventional approach.

This paper is limited to our experience and it is not based on empirical data; nevertheless, it aims at turning the spotlight on a groundbreaking approach which could prove to be a very effective teaching tool. We hope our experience will inspire other teachers to go beyond the boundary of their disciplines to meet their students' needs.

The first part deals with this new approach from a terminological point of view and embraces transdisciplinarity as the key to effective teaching and learning. The second describes our teaching module inspired by the concept of transdisciplinarity, which is new as a tool for meaningful and relevant teaching. Finally, the third part concludes the article by reporting teachers' considerations and students' feedback on the strengths and weaknesses of an experience whose main outcome is our new perspective to working in education.

\section{Terminological clarifications}

When we talk about teaching, we come across terms such as multidisciplinary, interdisciplinary and crossdisciplinary derived from the word discipline(s), considered by 
Gardner (2013) as arenas for understanding, able to structure children's intuitive knowledge into an increasingly complex thought with the aim of achieving understanding (p. 7). To clarify this abundance of terms, we began a series of readings and soon realized that the literature on the subject is extensive and multidisciplinary itself: experts from various sectors have written on transdisciplinarity, confirming the existence of an interest that crosses the boundaries between disciplines and different geographical areas and is considered essential to understanding the complexity of reality.

According to Stember's classification (1991, p. 4), the approach in which one discipline is considered from the perspective of another is defined as crossdisciplinary; the multidisciplinary methodology, on the other hand, sees experts from different disciplines working together starting from their disciplinary skills, while the interdisciplinary methodology integrates the knowledge and methods of different disciplines using a synthesis of approaches.

Nicolescu (2002, p.1) takes this classification and emphasizes the disciplinary quality of the former approaches; the novelty of his thought consists in the rediscovery of the concept of transdisciplinarity introduced by Piaget, in which the boundaries between disciplines are almost non-existent, as can be seen in the following representation by Jensenius (2012).
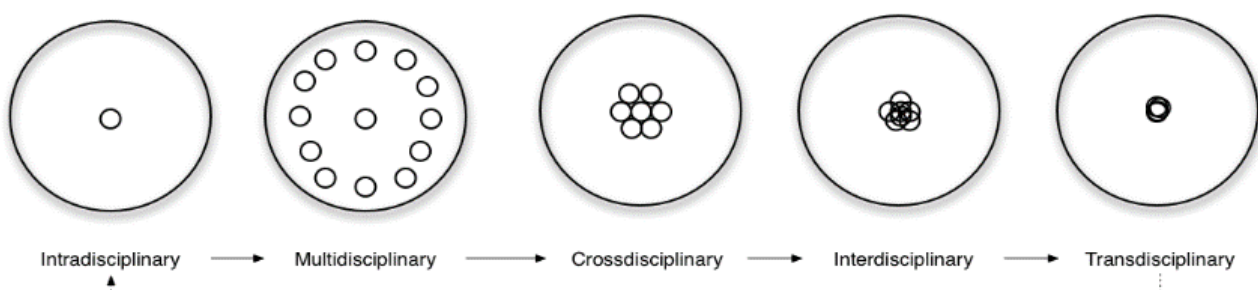

Figure 1 The different disciplinarities from Jensenius (2012)

Starting from the new idea of multiple levels of reality derived from quantum physics, Nicolescu identifies transdisciplinarity as the best suited methodological and pedagogical strategy "to meet the unprecedented challenges of our troubled world" which is deeply affected by the miraculous growth of knowledge enhanced by technological breakthroughs (Nicolescu 2002, p. 1). Although we have no skills in quantum physics, we became fascinated by this globally open way of relating to the complexity of reality, which does not provide reassuring unambiguous explanations or certainties. Actually, this approach shows us a new way of thinking and experiencing society through the unity of knowledge, which is no longer divided into single disciplines. The transdisciplinary approach, in fact, problematizes the information that circulates between disciplines and beyond them (Dinca, 2011, pp. 5-6); it is realized through a unity of structures and intellectual models overcoming disciplinary boundaries in a holistic and integrated perspective by overlapping the sectors and erasing 
their borders. Quoting Piaget, Nicolescu (1997, p. 2) argues that fluctuations between disciplinary borders can generate new and more meaningful knowledge. It is precisely the power of this message that, as maintained by Recalcati (2014), can involve students and make them fall in love with the teacher's contribution, which can become significant again and bring the school back to the centre of society (p. 4).

Furthermore, transdisciplinarity as a tool for the integration of knowledge is a topic closely related to the global citizenship education proposed by UNESCO in 2015 (Ruano, Galeffi, Ponczek, 2014), which recalls the cosmodernity paradigm. This label is used by Nicolescu for a new consciousness based on the interaction between science, culture, spirituality, religion and society aiming at a more democratic and sustainable world (p. 22). This ability to think in a way that dissolves the hermetic boundaries between different disciplines can help students develop "a well-made head", as the philosopher Morin (2000) calls it in his famous essay; moreover, the transdisciplinary approach encourages flexible thinking that, as the historian Harari hopes (2018, p. 377), is able to interpret reality in its complexity by becoming a real forma mentis towards understanding; incidentally, this is also what the Italian state exam aims to assess (MIUR 2019).

Inspired by the similarities between the ministerial objectives for the state exam and the theories described above, we felt an imperative to set up an "arena" where students could experience the mutability of disciplinary boundaries while connecting information to reach a more global, holistic understanding of a complex phenomenon like the Great War. Unfortunately, we could not rely on previous transdisciplinary experiences or consolidated models of application of this approach to teaching in other secondary schools, as transdisciplinarity is not a mainstream teachers' attitude.

It was in this spirit of discovery and experimentation that we focused on the design of the module shown in the diagram below.

Table 1 Teaching Unit

The First World War: a transdisciplinary approach between literature, art and music

\begin{tabular}{ll}
\hline Teachers & Four English teachers, two Italian teachers, two Art History teachers \\
\hline Classes & $\begin{array}{l}\text { 6 classes of 23 students each, in an Italian secondary school; } \\
\text { students were aged 18, in the final year of high school }\end{array}$ \\
\hline Prerequisites & $\begin{array}{l}\text { Students should already know how to analyse a poem in terms of independently } \\
\text { identifying connections with the historical period; } \\
\text { Students have already done group work }\end{array}$ \\
\hline Content & The War Poets, Futurists, Modernism \\
\hline
\end{tabular}




\begin{tabular}{|c|c|}
\hline Goals & $\begin{array}{l}\text { Overcome boundaries between disciplines } \\
\text { Understand the period between the First World War and Modernism from } \\
\text { multiple points of view } \\
\text { Grasp the complexity of the war event and its repercussions on society as a whole }\end{array}$ \\
\hline \multirow[t]{22}{*}{ Schedule } & Step I: September 2018-October 2018 \\
\hline & $\begin{array}{l}\text { Course on multidisciplinarity, transdisciplinarity and interdisciplinarity for } \\
\text { secondary school teachers held by Prof. Borgogni from the University of Turin }\end{array}$ \\
\hline & Step II: October 2018 \\
\hline & $\begin{array}{l}\text { Lesson planning: The team of teachers planned the teaching unit, establishing } \\
\text { times and means of implementation. }\end{array}$ \\
\hline & Stage III: November 2018 \\
\hline & $\begin{array}{l}\text { Students attend a performance of Waltz in Wartime, on life in the trenches and } \\
\text { historical events between } 1914 \text { and } 1920 .\end{array}$ \\
\hline & Step IV: 21-24 January 2019 \\
\hline & $\begin{array}{l}\text { Remembrance week dedicated to the Great War, with } 2 \text { lessons devoted to } \\
\text { transdisciplinary activities in three main themes: }\end{array}$ \\
\hline & class 1: War Propaganda in Pictures and Pamphlets \\
\hline & $\begin{array}{l}\text { class 2: War propaganda in Poetry and Art (R. Brooke, The Soldier, Futurism in } \\
\text { poetry and art) }\end{array}$ \\
\hline & class 3: Trench poems (S. Sassoon, Suicide in the Trenches, Survivors) \\
\hline & $\begin{array}{l}\text { class 4: Trench poems (I. Rosenberg, Break of Day in the Trenches, J. McCrae, In } \\
\text { Flanders Field) }\end{array}$ \\
\hline & $\begin{array}{l}\text { class 5: Effects on society: shell shock (excerpts from V. Woolf, Mrs Dalloway, } \\
\text { focus on Septimus Warren Smith) }\end{array}$ \\
\hline & $\begin{array}{l}\text { class 6: Effects on society: women at war and suffragettes (excerpts from V. } \\
\text { Brittain. Testament of Youth) }\end{array}$ \\
\hline & Step V: 25 January 2019 \\
\hline & Study day: The Great War in Literature, Art \& Music \\
\hline & Transdisciplinary Lecture on Modernism held by Prof. D. Borgogni from the \\
\hline & $\begin{array}{l}\text { University of Turin } \\
\text { Concert lesson on Piano Concerto for the Left Hand written by Ravel for the }\end{array}$ \\
\hline & $\begin{array}{l}\text { Austrian pianist Wittgenstein, held by an Italian teacher with training in } \\
\text { musicology }\end{array}$ \\
\hline & $\begin{array}{l}\text { Presentation by the students of the work carried out in the individual classes on } \\
\text { the assigned themes (choral presentations of poems, dramatizations of texts } \\
\text { written by the students based on poems, exhibitions and commentary on } \\
\text { figurative works of the period) }\end{array}$ \\
\hline & Step VI: February 2019 \\
\hline & Reflection in class on the experience and collection of feedback \\
\hline
\end{tabular}

Step VII: 6 March 2019

Follow-up plenary meeting with Prof. Borgogni to compare the different teachers' experiences and to plan the drafting of a reflection paper on the activity

\section{Transdisciplinarity: challenges and opportunities}

This section is not based on empirical data, but it rests on the comments provided by the students and on the reflections shared by the teachers involved in the project "The First World 
War in literature, art and music". In hindsight, a question arises: despite good intentions, is it really possible to fully adopt a transdisciplinary teaching approach?

\subsection{Transdisciplinarity as teamwork and networking}

Teachers and students agreed that the initiative was stimulating and provided a new way to see the bigger picture with new eyes; however, at the same time, both groups believed that it was introduced too late, just to meet the needs of the state exam, and it only involved some subjects, not all.

It is common practice, especially in the humanities, to use musical passages or pictures to introduce topics, but in light of the terminological clarifications we are considering here (see par. 2), this practice appears multidisciplinary with interdisciplinary points and often turns out to be impromptu. To increase students' involvement and to make learning more relevant, teachers should merge methods and disciplines from the very beginning and throughout the course of study in order to help learners develop the mental habit of complex thinking that will enable them to face the world outside the classroom more consciously.

It is therefore necessary that the school board identify the conceptual issues and topics to be dealt with, promote transdisciplinary paths and highlight contact points in the daily teaching activities in order to facilitate a holistic and integrated perspective that crosses disciplinary boundaries. Furthermore, we believe that while safeguarding the freedom of teaching, the transdisciplinary approach is most effective if it is considered a mission of the whole institution, which adjusts teacher training and class scheduling accordingly.

Finally, the opportunity for dialogue and interaction should inspire the creation of networks of teachers and school managers who share this pedagogical principle (Jeder 2014, p. 129). Despite being aware of the challenges of organising a dialogue between different schools, we believe that new technologies such as digital platforms and discussion forums facilitate the sharing of good practices in the direction of education for complex thinking and the uniformity of evaluation between different institutions.

In our view, the transdisciplinary approach not only puts the student at the centre of the learning process, but it reactivates the teacher as the engine of pedagogical action, so we hope it will become the teachers' mainstream attitude. Being aware of the key role played by the individual teacher, in the following section we will reflect on a decisive aspect for the success of teaching in general and of transdisciplinary teaching in particular: the training of teachers.

\subsection{Transdisciplinarity as a categorical imperative for training}

Even if transdisciplinarity is a student-activating approach, it is the teacher who first must act by reflecting on and changing his/her own way of teaching. Approaching reality from a transdisciplinary perspective, showing initiative and working in teams and networks on 
issues from different points of view are the first actions to be taken for a school that is up to the task of preparing our students for the future. From personal experience, we can affirm that it is not an easy path and requires specific training: only in this way can we first understand the need for an integrated curriculum that considers the student a person eager to develop complex knowledge in response to the challenges of a complex world. Again, thanks to specific training, in our opinion, teachers can develop their transdisciplinary skills and enrich their teaching by sharing projects and modules aimed at developing the transdisciplinary perspective in students.

Scholars from different fields have showed that, through the search for knowledge and understanding outside the boundaries of the individual disciplines, teaching can once again play the key role in preparing new generations to meet the challenges of a technologicallyinterconnected world. However, the transdisciplinary approach needs further attention and research: empirical data, analyses and case studies are necessary in order to create a transdisciplinary pedagogy that can help teachers to adopt this approach in their classes.

\section{Conclusions}

The problem of a school lacking authority and efficacy is highlighted by Lacanian psychoanalyst Massimo Recalcati, who identifies the "illnesses" from which many teachers suffer: automatic pedagogical habits and repetition (Recalcati 2014, p. 6).

However, by adopting a transdisciplinary approach we firmly believe teachers can revitalise the learning environment in schools, stimulating curiosity and complex thinking skills and making school and the teacher's role more relevant than ever. As far as the ambition of this article is concerned, we hope that we have turned the spotlight on a very powerful teaching approach that could meet the urgent need to make teaching relevant to today's students, who are asking not to be left alone to face a fascinating but frightening world, in front of which sometimes even adults feel unprepared.

Nevertheless, we recognize that a single module was not enough to deeply affect our teaching or to have a long-lasting impact on our students; in order to develop a habit to complex thinking students should be helped to experience transdisciplinary activities from the beginning of their study career. Furthermore, research, scientific literature and consolidated models are needed to help develop a transdisciplinary pedagogy.

Paraphrasing a poem by the American poet Robert Frost, we can say we have taken the path less travelled by and we hope we have made a difference (Frost 1916, 9). There is still a lot to do, but nevertheless we believe that this is the direction teaching and pedagogic research should take. 


\section{Acknowledgements}

We thank all those who participated in various capacities in the realization of this paper and in particular Professor Daniele Borgogni and Professor Virginia Pulcini of the University of Turin, the School Manager, Dr. Giulia Guglielmini, colleagues from the Umberto I High School in Turin, and Jeaneen McAmis. Last but not least, I thank the senior students (school year 2018/2019) for the enthusiasm with which they faced our transdisciplinary adventure and the seriousness with which they reported comments and suggestions.

\section{References}

Collado Ruano, J., Galeffi, D.A., Ponczek, R. L. I. (2014). The Cosmodernity Paradigm: An Emerging Perspective for the Global Citizenship Education proposed by UNESCO. Transdisciplinary Journal of Engineering \& Science, (5), 21-34.

Dinca, I. (2011). Stages in the configuration of the transdisciplinary project of Basarab Nicolescu, from https: barasarb.nicolescu.perso.sfr.fr

Frost, R. (1916). The Road Not Taken. In Selected Poems, New York: Henry Holt and Company, from http://www.gutenberg.org/ebooks/21184

Gardner, H (2013). Understanding, Instructor's package, the Learning \& Mind series. Los Angeles: Into the Classroom Media

Harari Y. (2018). 21 Lessons for the 21st Century, London: Random House UK.

Jeder, D. (2014). Transdisciplinarity - the advantage of a holistic approach to life. Procedia - Social and Behavioral Sciences 137, 127 - 131.

Jensenius, A. R. (2012 12 March). Disciplinarities: intra, cross, multi, inter, trans. Message posted to http://www.arj.no/2012/03/12/disciplinarities-2/

MIUR (2015). LEGGE 13 luglio 2015, n. 107 Riforma del sistema nazionale di istruzione e formazione e delega per il riordino delle disposizioni legislative vigenti. (15G00122) GU n.162 del 15-7-2015. Roma: Repubblica Italiana https://www.gazzettaufficiale.it/atto/stampa/serie_generale/originario

MIUR (2019) Nota esplicativa Circolare $n^{\circ} 2197$. Roma: Repubblica Italiana. https://www.miur.gov.it/web/guest/-/circolare-n-2197-del-25-novembre-2019

Morin, E. (2000). La testa ben fatta. Milano: Cortina editore.

Nicolescu, B. (1997). The Transdisciplinary Evolution of Learning. In Proceedings of the International Congress on What University for Tomorrow? Towards a Transdisciplinary Evolution of the University, Locarno, 30 April-2 May 1997, 1-11. http://www.learndev.org/dl/nicolescu_f.pdf

Nicolescu, B. (2002). Manifesto of Transdisciplinarity. New York: SUNY Press.

Recalcati, M. (2014). L'ora di lezione. Torino: Einaudi.

Stember, M. (1991). Advancing the social sciences through the interdisciplinary enterprise, The Social Science Journal, 28 (1), 1-14. DOI: 10.1016/0362-3319(91)90040-B 